\title{
Nutrition Knowledge and Attitude Change of Students Studying in State and Private Secondary Schools
}

\author{
Ali Osman Kıvrak ${ }^{1}$, Mehmet Altın ${ }^{2}$ \\ ${ }^{1}$ Selcuk University, Faculty of Sports Sciences, Coaching Education Department, Konya, Turkey \\ ${ }^{2}$ Selçuk University, Faculty of Sports Sciences, Recreation Department, Konya, Turkey \\ Correspondence: Mehmet Altın, Selçuk University, Faculty of Sports Sciences, Recreation Department, Konya, Turkey.
}

Received: March 6, 2018

Accepted: April 20, $2018 \quad$ Online Published: April 23, 2018

doi:10.11114/jets.v6i6.3069

URL: https://doi.org/10.11114/jets.v6i6.3069

\begin{abstract}
The aim of this study is to analyse the changes in nutrition knowledge and attitudes of secondary school students depending on certain socio-demographic factors. The universe of the study is composed of 521 students, including 142 female and 379 male students studying in the secondary school and the sampling group in Konya province private and state central secondary education schools. The "Nutrition Knowledge and Attitude Scale", developed by Ertürk (2010), was used for nutrition attitude and knowledge and personal information form to acquire socio-demographic information. Descriptive statistics of the data were made, variance and homogeneity were tested, independent sample $t$ test was used for binary comparisons, One Way Anowa was utilized for multiple comparisons, and Tukey test was benefitted to determine difference sources. Nutrition knowledge of students in state schools was found to be lower than that of students in private schools and this gap was identified to be statistically significant $(\mathrm{P}<0.05)$. Nutritional knowledge and attitudes of female students were determined to be higher than males' and this difference was found to be statistically significant $(\mathrm{P}<0.05)$. Nutritional knowledge and attitudes of students who received elective nutrition classes were found to be higher than those who did not have nutrition classes and this change was again found to be statistically significant $(\mathrm{P}<0.05)$. The number of siblings and education status of parents were found to be statistically significant variants $(\mathrm{P}<0.05)$. As a result, the high level of nutrition knowledge and attitudes of female students compared to male students, the status and role of cultural transfer and social structure featured on male and female can be seen as the reason for that matter. It can be said that taking a nutrition class has a positive influence on nutrition knowledge and attitude, and that private school students have more nutrition knowledge yet similar nutrition attitudes with those in state schools.
\end{abstract}

Keywords: secondary education, state schools, private schools, nutrition, attitude

\section{Introduction}

According to the TSI (Turkey Statistical Institute) data, Turkey's young population constitutes $16.3 \%$ of the population. As of 2016, the total population is close to 80 million and the young population in the 15-24 age group range is determined as 12989042 people (TSI access 2017). It would not be false to say that the major problem of the young population in the world is nutrition, which is the greatest influence on the quality of life. According to the American Dietetic Association (ADA), all children and the young should be given rights to access food and nutrition programs that will provide physical, social and cognitive development without discrimination of age, gender, social status, colour, ethnicity, language, religion and health (Stang and Bayeri, 2003). Baysal (2007) referred the nutrition concept as behaviours that must be consciously made to get nutritional items essential for the body to maintain, improve, develop health and enhance the quality of life, with sufficient and balanced quantities and at appropriate times. Although the use of nutrition concept in the general sense is by itself, adequate and balanced nourishment fact is reserved in the concept. Adequate and balanced nutrition is to receive all the necessary nutritional items in sufficient and essential quantities, and to utilize those items appropriately in the body for the growth and working of the body and for the rehabilitation of the tissues. Nutrition is vital for growth, survival and protection of health (Spark, 1998; Müftüoğlu, 2003; Pekcan, 2008). Baysal (2012) emphasized that healthy society is the basic factor that determines the development of society, peace and development, and that the basic of health stands for adequate and balanced nutrition.

Nutrition knowledge is one of the factors affecting the nutritional status and habits of individuals, families and 
communities. Şanler and Ersoy (2005) propounded that one of the causes of inadequate and unbalanced nutrition in adolescence period is not having enough knowledge about nutrition and that this knowledge first develops in the family, then formed through the effects of teachers and environmental factors both during and pre-school years (Baltaci et al., 2008) .

Neumark-Sztainer et al., (2005) reported that primary factors in forming of young people's eating habits are personal food preferences, families' eating styles, parents' being model for food preference, media and community norms. On the other hand, Uyar Barut (2007) emphasized that socioeconomic level of a society, rapid population increase, insufficient food production and distribution, impairment of environmental conditions, lack of nutritional knowledge and related misapplications affect health in a negative sense. As for the social-environmental factors, influencing eating habits are family, friends and other immediate environment (Story et al., 2002). Nutritional requirements are influenced by factors such as age, gender, physical activity, existing diseases and genetic structure. The amount of energy and nutrients required during adolescence period is greater than that of adults (Saygin et. al., 2011). Adolescence is a special period that includes the transition from childhood to adulthood, during which time growth and development in human life are at the fastest levels (Pekcan, 2004). Along with the rapid growth, development and changes in metabolic rate, which are the most important features of adolescence, nutritional requirements increase. It is quite substantial to provide the daily energy and nutrient requirements in the form of regular meals and with appropriate nutrition patterns at each meal (Baltac1 et al., 2008). Permanent attitudes and habits can be acquired while physical, cognitive and psychosocial developments in adolescence continue. In the literature; (Gökçay and Garipağaoğlu 2002; Hasbay, 2004), it is emphasized that, thanks to certain attitudes and behaviours gained in childhood and adolescence; some diseases can be prevented in the future (Gökçay and Garipağaoğlu, 2002; Hasbay, 2004).

Özyazıcıoglu et. al., (2011) pointed out that the increase in the areas of interest during the youth period (15-24 years) referred to as the period of preparation and maturation for life, is the transition period from processes such as the desire for independence, time spent with peers outside and future anxiety. Unhealthy nutrition, one of the most frequently encountered risky behaviours in adolescents, leads to mental and cognitive developmental impairment, behavioural and psychological problems, and obesity (Petrillo and Meyers, 2002). Adolescence in literature, is entitled as a period in which attitudes and habits that will continue throughout the life of the individual are settled (Tezcan et. al., 2002; Kann et. al., 2000) and the concept of nutrition culture, which has a great impact on quality of life, becomes even more significant in this period. Educational institutions have a structure that allows children and young people to spend almost half of their time at schools. Education programs and experiences affect the foundation and development of the nutrition attitudes and habits of young people. It has been reported in the literature that the rate of regular breakfast habits which is high in the primary school period decreases as the level of education progresses (Tezcan et. al., 2002; Mazıcıoğlu and Öztürk, 2003).

Fişek (1983) reported that inadequate and unbalanced nourishment in our country is a major social problem. This result has not been qualified enough to solve the concept of social nutrition problem indicated by Fişek (1983), despite of the improvements related to nutrition and the enrichment in the literature, nutrition attitudes, knowledge and habits. It should not be forgotten that nourishment is as sociological and psychological as it is physiological (Çalıştır et. al., 2005). It has been appointed in the literature that inadequate and unbalanced nourishment has negative effects on mental development as well as physical development. It is also stated that this kind of nourishment causes learning disabilities, behavioural disorders and a decline in the average of intelligence (Oktar and Şanlıer, 2003). To be healthy in physical and mental aspects and to maintain the health in every phase of life is only possible with adequate and balanced nutrition (Tanir et. al., 2001). Especially during the youth period, it is crucial that the nutrition is adequate and appropriate to body needs (Açık et. al., 2003). Adolescence is the period in which healthy nutritional habits are gained and lifestyle behaviours are set. The habits gained in this period are vital in terms of protecting adults from nutritional-related chronic diseases (WHO, 2005; Baltacı et. al., 2008).

Being overweight, namely obesity, is one of the ongoing nutritional problems in adult life that starts in the youth period (Gökçay and Garipağaoğlu, 2002). Malnourishment is as harmful as over nourishment for human health. Our knowledge and habits will guide us to a regular and balanced nutritional attitude. It would not be wrong to say that our adolescence period and educational experiences are great opportunities to upgrade our life qualities to a better level. Young people who perceive nourishment as taking nutritional items randomly only when they are hungry and who save the day merely with fast food have been becoming obese and struggling with health problems day by day. For the first time, the World Health Organization has used the epidemic (infectious) phrase for a non-infectious disease. Eating behaviour is a culture; habit, attitude and knowledge are the determinants of this behaviour.

\section{Material and Method}

The universe of the study is constituted by secondary school students and the sample group by 521 students, 142 female 
and 379 male studying at Konya province central state and private schools. The "Nutrition Knowledge and Attitude Scale", developed by Ertürk (2010), was used for nutrition attitude and knowledge and personal information form to acquire socio-demographic information. The "Likert Scale" was utilized for the evaluation of the part about the nutrition knowledge and attitude of the test. This scale is a measure intended to determine the individual behaviour scores of an individual. Different numbers of options are determined for each of the $\mathrm{K}$ problems. The options are sequentially ordered in sequential order. On this scale, those who absolutely agree on the right knowledge and attitudes are given +2 , +1 for those who agree, 0 for those who are not sure, -1 for those who disagree, and -2 for those who absolutely disagree. The questionnaire used in our research has 27 questions about nutrition knowledge and 11 suggestions about attitude. The maximum nutrition knowledge score was set at 54 and the attitude score at 22 if they answered correctly to all proposals. Variance and homogeneity of the data were tested, independent sample t test was used for binary comparisons, One Way Anowa was utilized for multiple comparisons, and Tukey test was benefitted to determine difference sources.

\section{Findings}

Table 1. Changes in nutrition knowledge and attitudes of students depending on factors such as School Type, Gender, Sportive Activity and Nutrition Education Status

\begin{tabular}{|c|c|c|c|c|c|c|c|}
\hline \multirow{2}{*}{ School Type } & \multirow{2}{*}{$\mathbf{n}$} & \multicolumn{2}{|c|}{ Nutrition Knowledge } & \multirow{2}{*}{$\mathbf{P}$} & \multicolumn{2}{|c|}{ Nutrition Attitude } & \multirow{2}{*}{$\mathbf{P}$} \\
\hline & & $\mathbf{x}$ & Ss & & $\mathbf{x}$ & Ss & \\
\hline State School & 253 & 67,5850 & 11,57505 & \multirow{2}{*}{, $000^{*}$} & 31,2964 & 6,15048 & \multirow{2}{*}{, 175} \\
\hline Private School & 268 & 72,5522 & 13,53429 & & 32,0299 & 6,17709 & \\
\hline \multicolumn{8}{|l|}{ Gender } \\
\hline Female & 142 & 73,7817 & 13,46659 & \multirow{2}{*}{, $000^{*}$} & 32,6690 & 5,94147 & \multirow{2}{*}{, $022^{*}$} \\
\hline Male & 379 & 68,7757 & 12,35754 & & 31,3008 & 6,21904 & \\
\hline \multicolumn{8}{|l|}{ Sportive Activity } \\
\hline Doing Sports & 217 & 70,8157 & 12,16336 & \multirow{2}{*}{,304 } & 31,9309 & 6,10933 & \multirow{2}{*}{,421 } \\
\hline Not Doing Sports & 304 & 69,6579 & 13,31968 & & 31,4901 & 6,21506 & \\
\hline \multicolumn{8}{|c|}{ Nutrition Education Status } \\
\hline Received Classes & 129 & 73,1938 & 13,15240 & \multirow{2}{*}{, $001^{*}$} & 33,2946 & 6,13825 & \multirow{2}{*}{, $002^{*}$} \\
\hline Did Not Receive Classes & 392 & 69,1352 & 12,60676 & & 31,1403 & 6,09332 & \\
\hline
\end{tabular}

*Significant Difference among the groups

According to Table 1, nutrition knowledge of state school students $(67,59 \pm 11,58)$ is lower than that of private school students $(72,55 \pm 13,53)$ and this change was found to be statistically significant $(\mathrm{P}<0.05)$. There is no statistical change observed in nutritional attitudes between state and private school students.

While there is no statistically significant change observed depending on the sportive activity factor, there exist statistically significant changes in nutrition attitude and knowledge depending on gender $(\mathrm{P}<0.05)$. Nutrition knowledge $(73,78 \pm 13,47)$ and nutrition attitude $(32,67 \pm 5,94)$ average of females was found higher than males' nutrition knowledge $(68,78 \pm 12,36)$ and nutrition attitude $(31,30 \pm 6,22)$ average and this change was found to be statistically significant $(\mathrm{P}<0.05)$.

Statistically significant changes were observed between students who took elective nutrition classes and those who did not $(\mathrm{P}<0.05)$. Nutritional knowledge $(73,19 \pm 13,15)$ and nutritional attitude $(33,29 \pm 6,14)$ values of the students who took elective nutritional classes were found higher than nutrition knowledge $(69,14 \pm 12,61)$ and nutrition attitude $(31$, $14 \pm 6,09)$ values of the students who did not take the classes and this change was found to be statistically significant (P $<0.05)$. 
Table 2. Changes in nutrition knowledge and attitudes of the students depending on grade, number of siblings, parent's education level factors

\begin{tabular}{|c|c|c|c|c|c|c|c|}
\hline \multirow{2}{*}{ Grade Levels } & \multirow{2}{*}{$\mathbf{n}$} & \multicolumn{2}{|c|}{ Nutrition Knowledge } & \multirow{2}{*}{$\mathbf{P}$} & \multicolumn{2}{|c|}{ Nutrition Attitude } & \multirow{2}{*}{$\mathbf{P}$} \\
\hline & & $\mathbf{x}$ & Ss & & $\mathbf{x}$ & Ss & \\
\hline $9^{\text {th }}$ Grade & 188 & 69,8989 & 11,97928 & \multirow{4}{*}{,462 } & 32,0638 & 5,88719 & \multirow{4}{*}{, 523} \\
\hline $10^{\text {th }}$ Grade & 172 & 70,7209 & 11,52638 & & 31,7326 & 5,33097 & \\
\hline $11^{\text {th }}$ Grade & 95 & 71,0105 & 12,57276 & & 30,9158 & 6,21368 & \\
\hline $12^{\text {th }}$ Grade & 66 & 68,0606 & 17,99306 & & 31,5000 & 8,53455 & \\
\hline
\end{tabular}

\section{Number of Siblings}

\begin{tabular}{llllllll}
\hline No Siblings & 15 & 74,2000 & 12,26610 & & 32,2667 & 5,75036 & \\
1 Sibling & 93 & 69,9140 & 12,02954 & & 31,7312 & 6,29033 & \\
2-3 Siblings & 232 & 71,8233 & 12,54425 &, 11 & 32,1552 & 5,87253 &, 084 \\
4-5 Siblings & 137 & 69,2482 & 12,97213 & & 31,5182 & 6,00625 & \\
6 and over Siblings & 44 & 68,1364 & 13,68345 & & 29,2955 & 7,62974 & \\
\hline
\end{tabular}

Mother Education Level

\begin{tabular}{|c|c|c|c|c|c|c|c|}
\hline Primary & 249 & 71,2169 & $13,47313^{\mathrm{a}}$ & \multirow{4}{*}{, $022^{*}$} & 32,2450 & 6,46456 & \multirow{4}{*}{, 157 } \\
\hline Secondary & 129 & 70,7519 & 12,08694 & & 31,4806 & 5,37951 & \\
\hline Higher Education & 101 & 68,7921 & 12,71953 & & 31,0693 & 6,11924 & \\
\hline Master/PhD & 42 & 65,1190 & $10,36693^{\mathrm{b}}$ & & 30,3333 & 6,58774 & \\
\hline
\end{tabular}

Father Education Level

\begin{tabular}{lllllll}
\hline Primary & 164 & 72,0427 & $12,00171^{\mathrm{b}}$ & 32,3841 & 5,80078 \\
Secondary & 111 & 71,1532 & $13,06710^{\mathrm{b}}$ &,$_{005^{*}}$ & 32,1532 & 5,65878 \\
Higher Education & 146 & 69,7534 & 14,16385 & 31,3767 & 6,71297 &, 060 \\
Master/PhD & 100 & 66,4600 & $11,21365^{\mathrm{a}}$ & & 30,4100 & 6,33109 \\
\hline
\end{tabular}

*,\#, a,b= Significant Difference among the groups

As can be seen in table 2, there is no change in nutrition knowledge and attitudes of the students depending on the grade and the number of siblings. It was, on the other hand, determined that the nutrition knowledge of individuals $(71,22 \pm$ $13,47)$ with primary school graduate mothers was higher than the ones who had master/PhD graduate mothers $(65,12 \pm 10,37)$ and this change was found to be statistically significant $(\mathrm{P}<0.05)$. There is no change observed in nutritional attitudes depending on mother education levels.

It was also determined that the nutrition knowledge of the individuals $(72.04 \pm 12.00)$ with primary school graduate fathers is higher than the ones who had master/PhD graduate fathers $(66.46 \pm 11.21)$ and this change was found to be statistically significant $(\mathrm{P}<0.05)$. There is no change observed in nutritional attitudes depending on father education levels.

\section{Discussion and Conclusion}

Via this study, it is intended to examine the changes in nutrition knowledge and attitudes of secondary school students depending on certain socio-demographic factors. Nutritional knowledge of students attending at state schools was found to be lower than private school students' knowledge and this change was observed to be statistically significant $(\mathrm{P}$ $<0.05)$. There was no statistical change observed for nutritional attitudes between state and private school students. Although private school students have more nutrition knowledge than state school students do, it is observed that their nutritional attitudes have not changed. It can be said that a common behaviour pattern is exhibited when the issue is about nutrition attitudes, despite the nutrition knowledge of the individuals continuing to develop in the same cultural texture and environment is different.

In our study, while there was no statistical change observed for the sportive activity factor, statistically significant changes were observed in nutrition attitude and knowledge depending on gender $(\mathrm{P}<0.05)$. Nutritional attitudes and knowledge values of females were found to be higher than males and this change was determined to be statistically significant $(\mathrm{P}<0.05)$. Ayhan et. al., (2012) in their study in which they analyse medical students' eating habits and the factors affecting these habits, reported that females were more regularly fed than males. Şanlier et. al., (2009) determined no statistically significant differences in body mass indexes of male and female students but reported that females had higher nutritional habits, behaviours and nutrition knowledge scores than males. Vançelik et al., (2007) found out that the average score of nutrition habits was statistically higher in males than in females. Demirezen and Coşansu, (2005) in their study in which they evaluate the eating habits of adolescents, reported that $99.8 \%$ of the 
students were at different levels of risk in terms of eating habits and that the risk levels in males were higher than that of females. In the same study, it was pointed out that adolescents in the study group carry a risk in terms of their eating habits in general terms and risk behaviours are higher in male students (Demirezen and Coşansu, 2005). These studies are important in terms of showing parallelism with our findings.

Statistically significant changes were observed between students who took elective nutrition classes and those who did not $(\mathrm{P}<0.05)$. Nutritional knowledge $(73,19 \pm 13,15)$ and nutritional attitude $(33,29 \pm 6,14)$ values of the students who took elective nutrition classes were found to be higher than nutrition knowledge $(69,14 \pm 12,61)$ and nutrition attitude $(31,14 \pm 6,09)$ of the students who did not take the classes and this change was found to be statistically significant (P $<0.05)$. Çetin and Sarper, (2013) notified that medical school education had a positive effect on students' nutritional knowledge levels. It can be said that nutrition education will also influence nutritional attitudes when supported by high-level educational factors. Türk et al., (2007) reported that students had adequate nutrition knowledge, yet frequently included unhealthy foods in their diets. Özmen et al., (2007) observed that skipping a meal in high school students is a common eating habit and that many adolescents do not eat regular three-times-a-day meals. A similar finding is put forward in a study by Erten (2006). In the study, it is ascertained that $27.7 \%$ of university students received nutrition education and that these students were more cautious about balanced diet and the number of regular meals. Such irregularities in adolescents will cause them to struggle with problems such as permanent irregular and unbalanced nutrition habits during the completion of their development or in future life. Cockburn et. al., (2014) reported that the nutrition knowledge of coaches who took nutrition classes was at better levels. Researches that have similar findings to our study have pointed to the same conclusions in this sense. Ulaş and Genç, (2010) stated that different education programs and strategies for healthy nutrition should be developed by emphasizing that it would not be sufficient if individuals do not reflect their right knowledge to their behaviours. It is thought that the problem can be solved by convincing young people about the fact that nutrition knowledge is indeed essential for them in cognitive sense.

In this study, no change was observed in nutrition knowledge and attitudes of students depending on the grade and the number of siblings. In their study on nutrition knowledge and habits of students from medical school first and the sixth grades, Çetin and Sarper, (2013) reported that sixth grade students had more accurate answers to basic nutrition knowledge questions than first grade students had, and that the sixth graders had more nutrition knowledge scores. Conclusions of the study by Çetin and Sarper, (2013) contradict to our findings in this aspect. The reason of this differentiation can be due to the age group, environment, socio-cultural structure and educational factors. The reason why there is no change in nutrition knowledge and attitude depending on the number of siblings can be due to the education system, the same economic, socio-cultural structure. It can be considered that the same kind of living conditions contributed to this result no matter if the numbers of siblings vary or not.

It was determined that the individuals with parents who have primary education graduations parents had a higher level of knowledge than those who had master/ $\mathrm{PhD}$ graduate parents and this change was found to be statistically significant (P <0.05). Türk et. al., (2007) in their study devoted to nutrition habits of first grade high school students from urban district, reported that creating healthy nutrition habits and gaining access to healthy food are possible and that parents, schools and society itself are responsible for that. Papadaki et. al., (2007) ascertained that eating habits of students living far away from their parents vary; fruit and vegetable consumption decreases while fatty food consumption increases. It is a quite noteworthy point that the nutrition knowledge of students with parents who have higher education levels is lower than those of with primary school graduate parents. The fact that the gap in education level can be covered with the interest and approach shown to children has shaped the opinion that parent education can be seen as merely a demographic feature when children have right nutrition knowledge and attitude. The important issue is that students are able to have regular and adequate nutrition habits in their own educational experiences rather than parental education level.

In conclusion, nutritional knowledge of students in state schools was found to be statistically lower than that of students in private schools but this did not seem to be reflected in their nutrition attitudes. It was also observed in this study that females had higher nutritional knowledge and attitude than males and students who took nutrition classes had more nutrition knowledge and attitude levels than those who did not. It is considered that creating a sufficient space for nutrition culture and knowledge in education programs and experiences is crucial in terms of having positive impacts on lifestyle and determining the nutritional knowledge, attitudes and behaviours during especially adolescence period, which is the last transition phase to adulthood and a critical one.

\section{References}

Açık, Y., Çelik, G., Ozan, A. T., Oğuzöncül, A. F., Deveci, S. E., \& Gülbayrak, C. (2003). Nutrition Habits of University Students. Health and Society, 13(4), 74-80. 
Ayhan, D. E., Günaydın, E., Gönlüaçık, E., Arslan, U., Çetinkaya, F., Asımı, H., \& Uncu, Y. (2012). The Nutrition Habits of Uludağ University Medical Faculty Students and the Factors affecting them. Uludağ University Medical Faculty Magazine, 38(2), 97-104.

Baltacı, G., Ersoy, G., Karaağaoğlu, N., Derman, O., \& Kanbur, N. (2008). Healthy nutrition and active life in adolescents. T.R. Ministry of Health General Directorate of Primary Health Care Services Department of Nutrition and Physical Activity. Physical Activity Information Series. Klasmat Publications, Ankara.

Baysal, A. (2007). Nutrition. Hatiboğlu Publications, $11^{\text {th }}$ edition, Ankara.

Baysal, A. (2012). Nutrition. Hatiboğlu Publications, $14^{\text {th }}$ edition, Ankara.

Cockburn, E., Fortune, A., Briggs, M., \& Rumbold, P. (2014). Nutritional Knowledge of UK Coaches, Nutrients, 6(4), 1442-1453. https://doi.org/10.3390/nu6041442

Çalıştır, B., Dereli, F., Eksen, M., \& Aktaş, S. (2005). The Determination of Nutrition Knowledge Levels of Muğla University Students. International Journal of Human Sciences, 2(2), 1-8.

Çetin, G., \& Sarper, F. (2013). A Research on Nutrition Knowledge and Habits of First and Senior Graders at Medical Faculty. Education and Society in the $21^{s t}$ Century 2(6), 84-104.

Demirezen, E., \& Coşansu, G. (2005). Evaluation of Eating Habits in Adolescents. STED, 14(8), 174-178.

Erten, M. (2006). A Research on Nutrition Knowledge and Habits of University Students in Adiyaman. T.R. Gazi University, Institute of Educational Sciences, Department of Family Economics and Nutrition Education, Master Thesis, Ankara.

Ertürk, Ş. (2010). A Study on the Effects of Nutrition Knowledge, Attitudes and Habits, Body Composition and Haemoglobin Levels on the Performance of 18-22 Year Old Male Students Selected for University Athletics Team. Hacettepe University, Institute of Health Sciences, Department of Nutrition and Dietetics, Ph.D., Ankara.

Fişek, N. (1983). Introduction to Public Health. Ankara Çağ Printing House, 70-73.

Gökçay, G., \& Garipağaoğlu, M. (2002). Nutrition in Childhood and Adolescence. Saga Publications. 118-124.

Hasbay, S. A. (2004). Importance of Nutrition and Physical Activity in School Children. Clinical Children Forum, 4(1), 32-37.

Kann, L., Kinchen, S. A., Williams, B. I., Ross, J. G., Lowry, R., \& Kolbe, L. (2000). Youth risk behaviour surveillanceUnited States, 1999, MMWR (Mortality and Morbidity Weekly Report), 49, 1-31.

Mazıcıoğlu, M., \& Öztürk, A. (2003). Nutrition Habits of $3^{\text {rd }}$ and $4^{\text {th }}$ Grade University Students and the Factors affecting them. Erciyes Medical Journal, 25(4), 172-178.

Müftüoğlu, O. (2003). Yaşasın Hayat. Doğan Publications INC., İstanbul, 32-87.

Neumark-Sztainer, D., French, S. A., Hannan, P. J., Story, M., \& Fulkerson, J. A. (2005). School Lunch and Snacking Patterns among High School Students: Associations with School Food Environment and Polices. International Journal of Behavioural Nutrition and Physical Activity, 2(1), 14. https://doi.org/10.1186/1479-5868-2-14

Oktar, İ., \& Şanlıer, N. (2003). Nutrition Programs Applied in Primary Schools and Opinions of Teachers Administrators on Nutrition Behaviour of Students. Gazi University Vocational Education Faculty, Vocational Education Magazine, 2, 1-8.

Özmen, D., Çetinkaya, A. Ç., Ergin, D., Şen, N., \& Erbay, P. D. (2007). Eating Habits of High School Students and Body Weight Controlling Behaviours. TSK Preventive Medicine Bulletin, 6(2), 98-105.

Özyazıcıoğlu, N., Kılıç, M., Erdem, N., Yavuz, C., \& Afacan, S. (2011). Determination of Healthy Lifestyle Behaviors of Students in Nursing Department. International Journal of Human Sciences, 8(2), 277-332.

Papadaki, A., Hondros, G., Scott, J. A., \& Kapsokefalou, M. (2007). Eating Habits of University Students Living at, or away from Home in Greece, Appetite, 49, 169-176. https://doi.org/10.1016/j.appet.2007.01.008

Pekcan, G. (2004). Nutrition in Adolescence Period. Clinical Children Forum, 4(1), 38-47.

Pekcan, G. (2008). Determination of Nutritional Status. Ministry of Health Publication, No: 726, Klasmat Publications. Ankara, 1-52. (ISBN:978-975-590-242-5).

Petrillo, J., \& Meyers, P. F. (2002). Adolescent Dietary Practices, A Consumer Health Perspective. Clearing House, 75, 293-296. https://doi.org/10.1080/00098650209603958

Saygın, M., Öngel, K., Çalışkan, S., Yağlı, M., Has, M., Gonca, T., \& Kurt, Y. (2011). The Eating Habits of Süleyman 
Demirel University Students. S.D.U Faculty of Medicine Journal, 18(2), 43-47.

Spark, A. (1998). Nutrition Counselling in Health Promotion throughout the Lifespan. Ed. Edelman CL, Mandle CL. Mosby Company, St.Louis.

Stang, J., \& Bayeri, C. T. (2003). Position of the American Dietetic Association: Child and Adolescent Food and Nutrition Programs. Journal of the American Dietetic Association, 103(7), 887. https://doi.org/10.1016/S0002-8223(03)00468-1

Story, M., Neumark-Sztainer, D., \& French, S. (2002). Individual and Environmental Influences on Adolescent Eating Behaviours. JADA, 102(3), 540-551.

Şanlıer, N., Konaklığlu, E., \& Gücer, E. (2009). Relationship between Nutrition Knowledge, Habits and Behaviours of Young People and Body Mass Indexes. G.U. Gazi Education Faculty Magazine, 29(2), 333-352.

Tanır, F., Şaşmaz, T., Beyhan, Y., \& Bilici, S. (2001). Nutritional Status of Workers in a Textile Factory in Doğankent. Journal of Turkish Medical Association Occupational Health and Safety, July, 22-25.

Tezcan, S., Aslan, D., Esin, A., Mutlu, M. F., Nalbantoğlu, B., Şenoğuz, M., ... Zümrütbaş, A. E. (2002). A Survey of the Dietary Habits and Status of $6^{\text {th }}, 7^{\text {th }}$, and $8^{\text {th }}$ Grade Students in a Primary School in Ankara. 8. National Public Health Congress, Diyarbakir, 733-735.

TUIKK. (Access 2017). http://www.tuik.gov.tr/PreHaberBultenleri.do?id=24648.

Türk, M., Gürsoy, Ş. T., \& Ergin, I. (2007). The Eating Habits of High School Freshmen in Urban Areas. General Medical Journal, 17(2), 81-87.

Ulaş, B., \& Genç, M. F. (2010). The Attitudes and Behaviours of the Staff working in the Malatya Military Hospital in 2007 on the issue of Healthy Nutrition. Inonu University Medical Faculty Magazine, 17(3), 183-193.

Uyar, B. B. (2007). Determination of Healthy Eating Indexes of Adults. HU Institute of Health Sciences Nutritional Sciences Program, Graduate Thesis, Ankara.

Vançelik, S., Önal, S. G., Güraksın, A., \& Beyhun, E. (2007). Factors related to Nutrition Knowledge and Habits of University Students. TSK Preventive Medical Bulletin, 6(4), 242-248.

WHO. (2005). Nutrition in Adolescence: Issues and Challenges for the Health Sector: Issues in Adolescent Health and Development. http://whqlibdoc.who.int/publications/2005/9241593660_eng.pdf

\section{Copyrights}

Copyright for this article is retained by the author(s), with first publication rights granted to the journal.

This is an open-access article distributed under the terms and conditions of the Creative Commons Attribution license which permits unrestricted use, distribution, and reproduction in any medium, provided the original work is properly cited. 